\title{
(1)

\section{THE INFLUENCE OF ENGLISH CAMP IN IMPROVING SPEAKING SKILL OF ENGLISH HOUSE COURSE STUDENTS IN MAROANGIN KABUPATEN ENREKANG}

\author{
Mustakim; Ismail Ismail \\ STKIP Muhammadiyah Enrekang \\ kimchangi00@gmail.com
}

\begin{abstract}
The objective of the research is to improve speaking skill of English House Course students through English camp strategy. This was an pre-experimental research using one group on pre-test and post-test design, the population of this research was the students of English House Course which has 80 students. Because the total number of the population was big enough, the researcher took 20 samples and applied random sampling technique; it means that one class of the population were taken as samples and the data was analyzed into percentage, mean score analyzes and the value of the t-test. The result of the data analyzes shows that the students' achievement on the pre-test was 71,7 and post-test was 86,1. This shows that English camp is a good strategy in English learning process at the students of English House Course Maroangin. After analyzing the data by using the t-test formula, the result of the t-test value $(11,86)$ was greater than $t$-table value $(2,093)$. This indicated that the hypothesis of research is accepted. There is a significant Influence of English camp program towards the students' achievement in English learning process. The researcher does English camp in English House Course Maroangin Kabupaten Enrekang for five days and it gives positive effect of students' skill in speaking. All item of learning achievement able to improve the students' speaking skill.
\end{abstract}

Key words: Speaking Skill, English Camp, English House Course, Students'achievement

\section{INTRODUCTION}

Language is an intimate part of social identity used by speakers in natural communication as a legitimate form of expression of human idea and feelings. English is the tool of communication between people in the world in every country. It is needed to develop sciences, technology, economic, education, art, and culture. English as an international language is very important to be mastered. Almost all communication in the world used English, especially in Indonesia. The functions of English are not only as a foreign language but also have an important role in accessing information of development of science and technology.

Language is a great ability of the human being in developing the knowledge for their future. There are four skills in English. The skills are very important to support the language skill (Ismail, Mustakim, 2018). They are speaking, reading, writing and listening. Teaching an English language cannot be separated from teaching speaking because speaking is one way to find information through oral communication in the world. Language is used to deliver or convey ideas, thought, experiences, feeling, and desires. Therefore, to utilize the language well, we 
should master the whole elements of language, including; vocabulary, pronunciation, and structure.

Many methods, strategies and techniques had been used by the teachers, lectures and instructors in teaching speaking but it had not been succeeded to improve the students' skill in speaking. Therefore, the English teachers must be creative to design a way or program in teaching English that will motivate to improve their speaking skill.

Depending on the pure facts at previously mentioned, this research will try to implement a new way to master speaking skill. English Camp is a strategy which is still familiar to the English teachers, lecturers and students. English camp is held for increasing students' speaking skill through teaching the elements (vocabulary, constructing sentence, and pronunciation) of language and speaking skill. Most of the English camp activities are formulated for upgrading students' speaking skill in real communication. Therefore, to complete this strategy, it should be integrated other techniques to master vocabulary. Vocabulary is a necessary component in communication. It is impossible for speakers to be able to deliver their idea without vocabulary.

In English camp, there are many activities to enhance speaking skill such as discussion, dialog, role play, free talking, games and meeting. These make the students easy to speak and have a good self-confidence. However, in English Camp the students are pressured to speak although any little error, easy going and keeping their feeling like in the real English society.

Based on the reality which is happening in English House Course Maroangin, some students have good skills in English but the others still need some supplements to support them in studying English. In teaching and learning English, it needs to apply many strategies to improve the learner skills. There are many strategies which have been applied in English House course but one of the strategies which have not been applied is English camp. This strategy is needed by the students because the students will feel free to ask or respond the material that given from the teacher. In other words, the students' self-confidence will be better in communicating among them rather than to the teacher meanwhile the students' selfanxiety can be under control by themselves (Ismail, 2017). English camp strategy has many methods that will help the students in mastering English and achieving the goal.

To know more about this English camp strategy, the researcher would like to do a research about "The Influence of English Camp in Improving Speaking Skill of English House Course Students In Maroangin".

\section{RIVIEW LITERATURE}

\section{The Concept of English Camp}

English Camp is the way to improve students' speaking ability. Most of the activities in English Camp are speaking skill, of course, because EnglishCamp was formulated as a good moment and gold opportunity to practice all the students' knowledge which had been studied.

According to English Thesaurus Dictionary, the term camp relates to an exclusive circle of people who live together temporarily with a common purpose.

The activities in English camp is made as like as in over side country. All communicate activities always done by English, therefore this situation made participants have to speak and practice their vocabularies and their sentences. To underline researcher's assumption previous, Moody recommended that to improve the quality of the student in learning English particularly in speaking 
skill, the students have to find their own strategy which suit on their interest and need in connection with this fact, the lecturer should give guidance and attention to stimulate the students to create their own strategies.

According to Salina (2011), the camp aims at training the students with necessary skills in order to be able to: (1) Communicate in English effectively; (2) Cooperate among themselves and develop leadership qualities; (3) Assume responsibilities; (4) Developing a sense of belongings; (5) Developing creative and critical thinking skills.

The camp exposes the students to good communicational skills, which can be used to achieve success in their command of the English language. It also provides opportunities for students to develop their natural in born skills further in the context of the English language. The students will be immersed in Englishspeaking environments. The camp is also designed to be enjoyable and intellectually stimulating. It will encourage cooperative work that leads the students to assuming responsibilities for their own progress.

It is clear from description that the skills obtained from the English camp program is in accordance with the incorporation of soft skills, namely communication, critical thinking and problem solving, teamwork, continuous skills and information management, entrepreneurial skills, ethics and professionalism, and leadership.

\section{English Camp Purpose}

English camp activities purpose is as an implementation of organization of learning activities to achieve educational goals. This can be classified as follows:

\section{General purpose}

In general, English camp activities to develop learning at the junior high school level education which can be described, among others:
As the implementation of teaching and learning process,

a. To enhance the teaching and learning process based on the demands of curriculum so that learners can learn effectively and efficiently,

b. To facilitate the teachers and students in learning,

c. Introduce the teachers and students that there are several method and learning programs that they can use as learning resources.

\section{Special Purpose}

a. Improving the ability of teachers and all students to enhance learning in accordance with the needs that have been determined primarily English subject,

b. Developing the KTSP broadly,

c. Improving learning achievement,

d. As one of the basic school curriculum development in accordance with the intended purpose,

e. Make it easy for teacher to implement the learning process

\section{The Activities of English Camp}

There are some courses offered during the training consists of general materials and materials plus a mixed in various activities as follows:

\section{Discussion}

The students may aim to arrive at a conclusion, share ideas about an event, or find solutions in their discussion groups. Before the discussion, it is essential that the purpose of the discussion activity is set by the teacher. In this way, the discussion points are relevant to this purpose, so that students do not spend their time chatting with each other about irrelevant things. For example, students can become involved in agree/disagree discussions. In this type of discussion, the teacher can decides groups of students, preferably 4 or 
5 in each group, and provide controversial sentences like "people learn best when they read vs people learn best when they travel". At the end, the class decides on the winning group who defended the idea in the best way for efficient group discussions. The group members can be either assigned by the teacher or the students may determine it by themselves, but groups should be rearranged in every discussion activity so that students can work with various people and learn to be open to different ideas. Lastly, in class or group discussions, whatever the aim is, the students should always be encouraged to ask questions, paraphrase ideas, express support, check for clarification, and so on.

\section{Professional Meeting}

Professional meeting is the introduction of types of formal meetings, the practice of formal meetings and also involve participant directly, for example by being the Master of Ceremonies (MC), Speaker for the opening ceremony, and also the speaker for closing ceremony.

\section{Free Talking}

This activity is an activity of communication between fellow participants in pairs, with topics that have been determined by the instructor, participants are free talk with their partner, using the English language instructors have a role to supervise the conversation between participants, and help the participants if there are participant who have difficulty vocabulary.

\section{Role play}

One other way of getting students to speak is role-playing. Students pretend they are in various social contexts and have a variety of social roles. In role-play activities, the teacher gives information to the learners such as who they are and what they think or feel. Thus, the teacher can tell the student that "You are David, you go to the doctor and tell him what happened last night, and...". Douglas recommended that role-play minimally involves (1) giving a role to one or more members of a group and (b) assigning an objective or purpose that participants must accomplish.

\section{Interviews}

Students can conduct interviews on selected topics with various people. It is a good idea that the teacher provides a rubric to students so that they know what type of questions they can asking or what path to follow, but students should prepare their own interview questions. Conducting interviews with people gives students a chance to practice their speaking ability not only in class but also outside and helps them becoming socialized. After interviews, each student can present his or her study to the class. Moreover, students can interview each other and "introduce" his or her partner to the class.

\section{Games}

This is a pattern of entertaining games with educational content, which involved participants. Games are held relating of the power of reasoning, and mastery of vocabulary, which helps participant build a memory and also serves as a refresher for the participant. There are many games such as brainstorming, zip zap, board game, picture card etc.

\section{Nicknames}

Nicknames is one of the role in English camp, the whole participants must change their original name into nickname. They are not allowed to call their original friend's name they must call their nickname. The nickname which they use is a vocabulary in English, it is aimed to get participants to increase their English vocabulary.

\section{Outdoor}

Outdoor is one of situation that use in English camp to make the participants 
got new atmosphere in new situation. Doing an activity in outdoor is different when the participant stay in the room. Some activities become more interesting when it is applying in outdoor. Some techniques in teaching like giving brain gym and doing gymnastic need large place and suitable condition and outdoor is one of ways that can be a good way. Another effect can be seen by the students' reaction. Comfortable place can build students' motivation in learning and it makes the students easy to achieve the real goal of what they have planned to be achieved.

The objective of this research are to find out whether or not English camp is able to improve speaking skill of English House Course students in Maroangin Kabupaten Enrekang and to find out how is the English camp able to improve speaking skill of English House Course students in Maroangin Kabupaten Enrekang

\section{METHODOLOGY}

\section{Research Design}

This research, the researcher collects; process; analyses the data to get conclusion of the research. This research is called quantitative research because it used numbers or statistics. The method applied in this research is pre-experimental design with one-group pre-test post-test design. The design is described as follow:

\section{E $\quad: 01 \quad X \quad 02$}

Figure 1 Pre-Experimental Method with one group pre-test and post-test design

Where:

$\begin{array}{ll}\mathrm{E} & =\text { Experimental Class } \\ \mathrm{O} 1 & =\text { Pre-test } \\ \mathrm{X} & =\text { Treatment }\end{array}$

$\mathrm{O} 2=$ Post-test

The location of this research was in English House Course Maroangin, Kabupaten Enrekang. The duration of this research was about 34 hours.

The population of the research was the students of English House Course Maroangin. It consists of six classes in English House Course Maroangin. The total of the populations were 80 students. Stating the number of population, the researcher drew samples by applying random sampling technique. This sample was researched from students of English House Course Maroangin. The researcher took one class. It was amount 20 students.

Table 2: Number of Sample

\begin{tabular}{ccc}
\hline Male & Female & Total \\
\hline 10 Students & 10 Students & 20 Students \\
\hline
\end{tabular}

To know the students' speaking skill and the students' speaking skill improvement, the researcher used speaking test that the students should answer the questions orally and the researcher also used a kind of observation namely diary description as instrument to collect the data. The test consists of five questions and the researcher gave the test orally to the students. Observation used to know the way English camp improves students' speaking skill and their improvements in learning process by applying English camp strategy.

In collecting data process of this study, the researcher collected the data with the following procedures:

\section{Pre-test}

Before continuing giving treatment, the researcher gave the students pre-test as an activity in the first meeting. The purpose was to know how far the students' speaking skill up to now. The test was delivered by the researcher dealing with 
the given materials. The following is the procedure of pre-test:

1. The researcher explained what the students are going to do.

2. The researcher called the students one by one.

3. The researcher tested the students and recorded their voice.

4. The researcher used mobile phone to record it.

5. The students' speech scored in their rating skill scale sheet by the researchers.

\section{Treatment}

After conducting the pre-test at the first meeting, the researcher gave treatment in four days. The students stayed-up at English camp program area during the treatment held.

Before starting the program, the students and instructors made some deals and agreements. These agreements became regulation and being a rule to manage the student's attitude and their spirit. After the instructor and the students have a deal, they have to signing up a lesson deal or learning contract and gone in this English camp by the contract.

\section{1) The first meeting}

1. The researcher gave greetings to the students.

2. The researcher asked the students to invoking to the God before studying.

3. The researcher gave motivation to the students to develop their speaking skill.

4. The researcher explained about the material (alphabet).

5. The researcher did repetition about the material.

6. The researcher ordered the students to memorize the alphabet (a-z \& z-

a)
7. The researcher divided the students into two groups.

8. The researcher prepared some alphabet cards. Each group took a set of alphabet card. After that each group played the game.

9. Each group has ten members. The first student started the game by taking one card in the table, and the first student mentioned the name of the alphabet correctly, then put the card off in the table (different side of the alphabet card). After that, the next student did what the first student has done. Next, the third student until the tenth student did the same way.

10. After all the groups have done the way of the game and the winner was a group who mentioned a lot of alphabet correctly than other groups.

11. The researcher appreciated the students.

12. The researcher closed the class.

\section{2) The second meeting}

1. The researcher explained about the material (spelling be).

2. The researcher gave the students opportunity to spell their name.

3. The researcher asked the students to spell their name nickname. After that, the researcher asked them to write five of their friends' name on the paper then spells it in front their friends.

4. The researcher gave comment to the students and appreciated them.

5. The researcher gave rote to the students that will be a password in the next meeting before entering the class.

6. The researcher closed the class by inviting one of students to reciting prayer.

\section{3) The third meeting}


1. The researcher gave greetings to the students.

2. The researcher asked the students to pray before studying.

3. The researcher gave motivation to the students to develop their speaking skill.

4. The researcher explained about the material (self-introduction)

5. The researcher gave some example about self-introduction.

6. The researcher asked the students to write the material.

7. The researcher divided the students in pairs then the students tried to introduce their self each other.

8. The researcher divided into some groups.

9. One of the students of their group introduced their self in another group.

10. The researcher asked some students to introduce their self in front of the class by standing on the stage.

11. The researcher gave conclusion about the lesson and gave motivation to the students.

12. The researcher gave greeting to the students.

\section{4) The fourth meeting}

1. The researcher gave greetings to the students.

2. The researcher asked the students to pray before studying.

3. The researcher gave motivation to the students to develop their speaking skill.

4. The researcher and her friends submitted rote list.

5. The researcher did an ice breaking before studying.

6. The researcher explained about the material (personal pronoun).

7. The researcher gave some example about the material.
8. The researcher gave opportunity to the students to ask about the material.

9. The researcher repeated the material.

10. The researcher divided the students in pairs.

11. The researcher prepared some picture cards.

12. The researcher asked the students to thinking, pairing and sharing with their partner about personal pronoun.

13. The researcher ordered the students to describing the pictures that they have taken.

14. The researcher closed the meeting by playing games.

15. The researcher continued to explain about "to be".

16. The researcher ordered the students to memorize the material.

17. The researcher divided the students in pair then ordering them to drilling the material.

18. The researcher ordered students to matching the pictures of personal pronoun which suitable with "to be cards" in the wall.

19. The researcher closed the meeting then continue the activities in outdoor.

\section{5) The fifth meeting}

1. The researcher gave greetings to the students.

2. The researcher asked the students to pray before studying.

3. The researcher gave motivation to the students to develop their speaking skill.

4. The researcher and her friends submitted rote list from the students.

5. The researcher gave brain gym to the students before studying.

6. The researcher explained about the material (daily routines). 
7. The researcher gave some example of daily routines.

8. The researcher gave opportunity to the students to ask about the material.

9. The researcher repeated the material.

10. The researcher divided the students in pairs

11. The researcher asked the students to do snowball throwing after explaining the rules of what they were going to do.

12. The researcher gave comment and closed the class.

\section{Post-test}

As the last day of English camp, the researcher conducted the post-test for the students. It aimed to measure the students' development in building up their speaking skill by English camp strategy.

1. The researcher explained what the students are going to do.

2. The researcher called the students one by one.

3. The researcher tested the students and recorded their voice.

4. The researcher used mobile phone to record it.

5. The students' speech scored in their rating skill scale sheet by the researchers.

\section{Observation}

Observation was distributed to the students while treatment. It was diary description. It was administrated to find out how the student achievement in learning speaking through English camp strategy. The researcher wrote ten statements. The researcher asked to her friends to be observer and the observer paid attention the students when treatment and the observer wrote notes about students achievement.
Technique of Data Analysis

The data was collected toward the test analysis quantitatively in percentage to measure participation to build up the students' speaking skill through English camp strategy.

Table 3 Classification the Students' Speaking Score

\begin{tabular}{ccc}
\hline No & Classification & Score \\
\hline 1 & Excellent & $86-100$ \\
\hline 2 & Good & $71-85$ \\
\hline 3 & Fair & $56-70$ \\
\hline 4 & Poor & $41-55$ \\
\hline 5 & Very poor & $\leq 40$ \\
\hline
\end{tabular}

\section{FINDING AND DISCUSSION}

The researcher administrated test in this research. The test was done twice. Pretest was given before the treatment. The researcher asked the student one by one orally and recorded the students' answer by using phone and posttest was given after the treatment. The researcher did some way in posttest and called the students one by one then gave the list of questions directly. The significant different between pretest and posttest located in the way the students answer the questions.

1. The Rate Percentage and scores of Pre test

To know more the students' score percentage of pretest, there are descriptive table below: 
Table 4 The Score Percentage of Pre-test.

\begin{tabular}{|c|c|c|c|c|}
\hline No & Qualifications & Scores & Frequency & Percentage (\%) \\
\hline 1 & Excellent & $8.6-100$ & 1 & $5 \%$ \\
2 & Good & $7.1-85$ & 15 & $75 \%$ \\
3 & Fair & $5.6-70$ & 1 & $5 \%$ \\
4 & Poor & $4.1-55$ & 3 & $15 \%$ \\
5 & Very Poor & $\leq 40$ & 0 & $0 \%$ \\
\hline & Total & & 20 & $100 \%$ \\
\hline
\end{tabular}

Based on the table above, 1 student got "excellent" (5\%), 15 students got "good" (75\%), 1 student got "fair" (5\%),
3 students got "poor" (15\%).The researcher concludes that the average of student's speaking skill is good.

Table 5 The Score Percentage of Post-test.

\begin{tabular}{|c|l|c|c|c|}
\hline No & \multicolumn{1}{|c|}{ Qualifications } & Scores & Frequency & Percentage (\%) \\
\hline 1 & Excellent & $8.6-100$ & 14 & $70 \%$ \\
2 & Good & $7.1-85$ & 6 & $30 \%$ \\
3 & Fair & $5.6-70$ & 0 & $0 \%$ \\
4 & Poor & $4.1-55$ & 0 & $0 \%$ \\
5 & Very Poor & $\leq 40$ & 0 & $0 \%$ \\
\hline & Total & & 20 & $100 \%$ \\
\hline
\end{tabular}

Based on the table above, 14 students got "excellent" (70\%), 6 students got "good" $(30 \%)$. It showed that most of the student got "excellent".

After the researcher had given treatment and done the post-test, the students' speaking had improved by teaching English camp. It was proved from the percentage result, many students got excellent and there were 6 students got good.

\section{The Mean Score of the Students on Pretest and Posttest.}

Table 6 Mean Score of Pre-test and Post-test.

\begin{tabular}{|c|c|c|}
\hline No. & Test & Mean Score \\
\hline 1. & Pre-test & 71,7 \\
\hline 2. & Post-test & 86,1 \\
\hline
\end{tabular}

Based on the table above, before giving the treatment in pre-test, the students' speaking got the mean score 
$(71,7)$ and after giving the treatment in post-test the students' mean score was $(86,1)$. It proved that there was improvement to the students' speaking skill through English camp.

Thus, $\mathrm{t}=11.86$. Assuming $p=0.05$ $(5 \%), \mathrm{d} f=19$. Commonly, when the $t$-test $>\mathrm{t}$ - table, is rejected and when $\mathrm{t}$-table $\leq \mathrm{t}-$ test is accepted. It means that the given treatment is effective in which there is a statistically significant main effect of treatment on student's improvement in speaking skill. T-table value is 2,093 than $\mathrm{t}$-test value is 11.86 . It showed that $\mathrm{t}$-test $>$ t- table.

\section{CONCLUSION}

Based on the result, it can be concluded that is rejected and there were significant influence on the students' improvement in speaking skill after English camp strategy has been applied.

\section{References:}

Brown, H Douglas. 2001. Teaching by Principles: An Interactive Approach to Language Pedagogy. San Fransisco State University. A Pearson Education Company.

Brown, H Douglas. 2004. Language Assesment Principles and Classroom Practise. San Fransisco State University.

Gay, L.R. 1981,Educational Research: Competencies for Analysis and Application. Second Edition.Charles E. Marril Publishing Company, USA.
Gay, L.R. 1981. Educational Research (Columbus, (ohio), Charles E. Meril Publishing.

H.L. Moody. 1972. The Teaching of Literature. London: Longman Publishing.

Harmer, Jeremy, 1998. How to Teach English. Edinburgh Gate: Addison Wesley Longman Limited.

Harmer, Jeremy. 1991. The Practice of English Language Teaching. New Edition. New York: Longman Publishing.

Heaton. J. B. 1988. Writing English Language Test. New York: Longman Group UK Limited.

I. Ismail., Mustakim.( 2018). Fundamental English Conversation. CV. Rasi Terbit.

Ismail Ismail. (2017). The Contribution of English Gossip Magazine on Students' Enthusiasm in Speaking Ability. Edumaspul-Jurnal Pendidikan. Vol. 2. (1), 1-14.

Mifflin, Houghton. 1984. English Grammar and composition. Houghton Mifflin Company. Boston. Printed in U.S.A.

Noor, Juliansyah. 2011. Metodologi Penelitian, Skripsi, Tjesis, Disertasi \& Karya Ilmiah. Jakarta: Kencana Prenada Media Group.

Torky, Shiamaa Abd EL Fattah. 2006. "The Effectiveness of a Task-Based Instruction Program in Developing English Language Skills of Secondary Stage Students" (Thesis Unpublished; Curricula and Methods of Teaching Department of Ain Shams University: Ain Shams. 